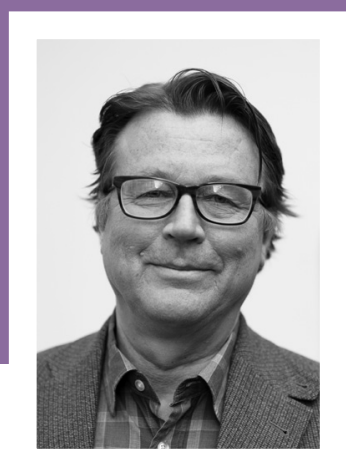

P̈̈̈̈KIRJOITUS

\title{
Mistä EI VOI PUHUA, ONKO SIITÄ VAIETTAVA?
}

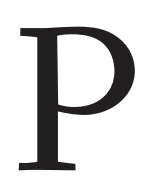

ÄÄMINISTERI JUHA SIPILÄN HALLITUS tiedotti elokuussa 2018 saavuttavansa yhden tärkeimmistä tavoitteistaan, 72 prosentin työllisyysasteen. Korkea työllisyysaste merkitsee parhaassa tapauksessa sitä, että aikuisväestö pystyy omalla työllään elättämään itsensä - ja vähän omaisiaankin.

Työllisyys on tärkeä tekijä verokertymän kannalta. Mitä suurempi osuus työikäisistä saa palkkaa tai muuta työtuloa, sitä laajempi on tuloveroa maksavien joukko. Korkeaa työllisyyttä pidetään arvokkaana myös moraalisista syistä: matala työllisyysaste kun viittaa siihen, että iso osa työikäisistä oleilee yhteiskunnan tuilla tekemättä mitään.

Korkean työllisyysasteen juhlistamista ei pitäisi pilata erittelemällä, mistä työllisyys muodostuu ja mitä kaikella tehdyllä työllä saadaan aikaan. Kaikki työ on arvokasta, sanotaan, ja työelämästä ulos pullautettujen pitäisi ottaa vastaan työ kuin työ.

Työtä ei pidä arvostella eikä työntekoa pidä kyseenalaistaa. Kuka siihen uskaltautuu, aiheuttaa aikamoisen älämölön, kuten kirjailija Ossi Nyman Röyhkeys-romaaninsa markkinointitempauksella vuosi sitten havainnollisti. Hän sanoi olevansa "ideologisesti työtön", eli kertoi Helsingin Sanomien haastattelussa välttelevänsä työnvälityksen tarjoamia turhia tai suorastaan vahingollisia töitä. Viidensadan euron työttömyyskorvauksella elävä esikoiskirjailija sanoi suostuvansa vain mielekkääseen työhön. Ei ideologisesti työtön kuitenkaan toimettomana päiviään viettänyt: joutessaan hän kirjaili hyväksi arvioidun romaanin, josta lukeva kansa saa ajattelemisen aihetta. Työttömällä oli sanottavaa, ja hän onnistui sanomaan sen.

Mutta tuohtumus, jonka Nyman yhdellä lehtihaastattelulla nostatti, oli suoranaista raivoa. Uudenmaan TE-toimiston johtaja ilmoitti pelkän lehtihaastattelun perusteella keskeyttävänsä hänen työttömyyskorvauksensa maksatuksen. Sanojaan aina harkiten asetteleva presidentti Sauli Niinistö joutui moraalisen paniikin valtaan menettäen hetkellisesti harkintakykynsä. Presidentti kauhisteli sitä, että kansalainen Nyman oli sanonut ääneen ja tietoisesti, ettei kaikki työ ole tekemisen arvoista.

LONDON SCHOOL OF ECONOMICSIN antropologian professori David Graeber käyttää tarpeettomista töistä käsitettä bullshit jobs. Suomessa puhutaan 'paskatöistä'. Antropologin silmin monet nyky-yhteiskunnassa palkkaa vastaan tehtävät toimet ja tehtävät näyttävät absurdeilta. Uudessa kirjassaan Bullshit Jobs - A Theory (Simon Schüster 2018) Graeber väittää, että suuri osa työstä on merkityksetöntä ja hyödytöntä, ellei jopa vahingollista.

Graeberin tarkoittamilla bullshit-töillä on suomen kielen paskatöihin verrattuna kuitenkin erityinen 


\section{MEISTÄ ON TULLUT PALKKATYÖHÖN JA \\ RAHAVÄLITTEISEEN KULUTUKSEEN PERUSTUVAN \\ TALOUDEN PANTTIVANKEJA.}

merkityksensä. Graeberin hevonpaskatyöt löytyvät toimistoista. Iso osa niistä on hallinto- ja johtotehtäviä. Eivätkä bullshit-työt suinkaan ole syntyneet vain julkisiin byrokratioihin. Ne ovat tyypillisiä myös suurten yritysten hallinto-osastoille. Raporttia syntyy niin, ettei kukaan jouda niitä lukemaan.

Graeberin näkyväksi tekemä ilmiö on saanut yleisössä vastakaikua juuri siksi, että niin moni ajattelee, ettei heidän vuodesta vuoteen tekemällään työllä ole mitään positiivista merkitystä. Hevonpaskatyön palkalla hyvin toimeentuleva ja yliopistossa itseään sivistänyt ihminen on alkanut arvioida tekemisiään ja ajankäyttöään kriittisesti: käytänkö aikani ja energiani niin, että tekemiseni helpottavat jonkun toisen elämää tai parantavat maailman tilaa laajemmin?

TARKOITUKSETON TYÖ on välittömästi vahingollista sille, jolla on vahva työetiikka ja jonka elämänsisältö riippuu työstä. Osa työllisyyttä lisäävästä ja bruttokansantuotetta kasvattavasta työstä ei ole ainoastaan merkityksetöntä tekijälleen vaan myös vahingollista muille ihmisille, muille lajeille ja ympäristölle.

Työelämän tutkimuksen grand old man Antti Kasvio kirjoittanut työn kestävyyden neljästä ulottuvuudesta. Taloudellisen kestävyyden ohella työtä on perusteltua arvioida ekologisen, inhimillisen ja sosiaalisen kestävyyden näkökulmasta. Työn merkityksellisyydestä ja tuotteiden haitallisuudesta on voitava puhua ilman, että työllisyyden nimissä puhuja julistetaan harhaoppiseksi.
On tietysti niin, että kun yhdet toimet tuhoavat ympäristöä ja sairastuttavat ihmisiä, on järkevää palkata toisaalle väkeä korjaamaan näitä tuhoja. Meistä on tullut palkkatyöhön ja rahavälitteiseen kulutukseen perustuvan talouden panttivankeja. On pakko kuluttaa, jotta yritykset saavat tuotteensa kaupaksi, ihmiset työstä elantoa ja julkinen valta veronmaksajia. Iso osa työstä menee siihen, että korjataan niitä jälkiä, joita neuvokkaasti markkinoitu kuluttaminen on aiheuttanut.

TYÖLLISYYDEN TABU ei saisi estää keskustelua globaalisti tärkeästä aiheesta. Kansalaisten olisi jo peruskoulussa hyvä oppia tarkastelemaan yhteiskuntaa kuten antropologit, outona koneistona, jossa yksi hieno mekanismi tuottaa vahinkoa, jota toisella mekanismilla koetetaan korjata.

Sivistynyt kansalainen kysyisi, onko siinä järkeä.

Heikki Silvennoinen 